\title{
The Arctic Sea ice in the CMIP3 climate model ensemble - variability and anthropogenic change
}

\author{
L. K. Behrens ${ }^{1,{ }^{*}}$, T. Martin ${ }^{1}$, V. A. Semenov ${ }^{1,2,3}$, and M. Latif ${ }^{1,4}$ \\ ${ }^{1}$ Helmholtz Centre for Ocean Research (GEOMAR), Kiel, Germany \\ ${ }^{2}$ A. M. Obukhov Institut of Atmospheric Physics, Russian Academy of Sciences, Moscow, \\ Russia \\ ${ }^{3}$ Lomonosov Moscow State University, Moscow, Russia \\ ${ }^{4}$ Kiel University, Kiel, Germany \\ "now at: Alfred-Wegener Institute, Bremerhaven, Germany
}

Received: 27 November 2012 - Accepted: 6 December 2012 - Published: 19 December 2012 Correspondence to: T. Martin (tmartin@geomar.de)

Published by Copernicus Publications on behalf of the European Geosciences Union.

The Arctic Sea ice in the CMIP3 climate model ensemble

L. K. Behrens et al.

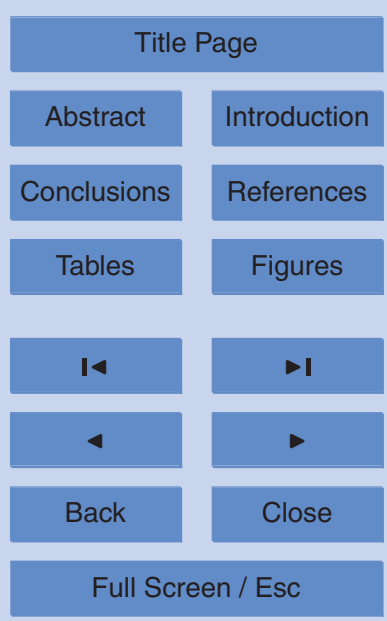

Printer-friendly Version

Interactive Discussion 


\section{Abstract}

The strongest manifestation of global warming is observed in the Arctic. The warming in the Arctic during the recent decades is about twice as strong as in the global average and has been accompanied by a summer sea ice decline that is very likely 5 unprecedented during the last millennium. Here, Arctic sea ice variability is analyzed in the ensemble of CMIP3 models. Complementary to several previous studies, we focus on regional aspects, in particular on the Barents Sea. We also investigate the changes in the seasonal cycle and interannual variability. In all regions, the models predict a reduction in sea ice area and sea ice volume during 1900-2100. Toward the end of the 21st century, the models simulate higher sea ice area variability in September than in March, whereas the variability in the preindustrial control runs is higher in March. Furthermore, the amplitude and phase of the sea ice seasonal cycle change in response to enhanced greenhouse warming. The amplitude of the sea ice area seasonal cycle increases due to the very strong sea ice area decline in September. The seasonal cycle amplitude of the sea ice volume decreases due to the stronger reduction of sea ice volume in March.

Multi-model mean estimates for the late 20th century are comparable with observational data only for the entire Arctic and the Central Arctic. In the Barents Sea, differences between the multi-model mean and the observational data are more pronounced. Regional sea ice sensitivity to Northern Hemisphere average surface warming has been investigated.

\section{Introduction}

The surface warming in the Arctic has been twice as strong as the global average warming during the recent decades (e.g. IPCC, 2007; Anisimov et al., 2007) The Arctic warming has been accompanied by a rapid summer sea ice decline that has considerably accelerated in the 21st century (Stroeve et al., 2007; Meehl et al., 2007; Stroeve

\section{The Arctic Sea ice in the CMIP3 climate model ensemble}

L. K. Behrens et al.

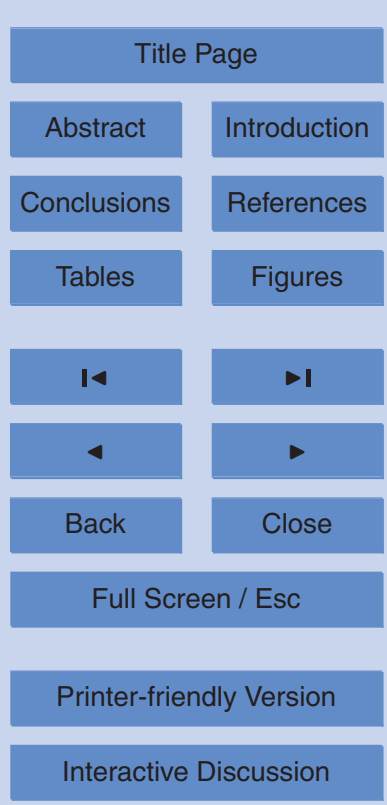


et al., 2012). Reconstructions suggest that current summer sea ice decline is likely to be unprecedented during the last millennium (Kinrad et al., 2011). The winter sea ice changes are smaller and there are indications that it may be comparable to the anomalously low sea ice during the Early 20th Century Warming time (Semenov and 5 Latif, 2012). Global climate models reproduce an Arctic sea ice decline during the 20th century, but generally with reduced amplitude, and predict a further decrease even with possibility (in some models) of an ice free Arctic in summer during the next decades (Wang and Overland, 2009). The model results, however, depict a very large spread. Stroeve et al. (2007) and Alekseev et al. (2009) have reported differences between 10 the observed and simulated decline in sea ice area. Alekseev et al. (2009) demonstrated that multi-model ensemble mean projections indicate a seasonally ice free Arctic Ocean around 2080, whereas extrapolation according to observational data trends indicate an ice free Arctic Ocean already within the next two decades Changes in sea ice thickness are also recorded (Meehl et al., 2007), although thickness observations 15 are sparse. The multi-year sea ice decreases (Kwok et al., 2009), whereas the firstyear sea ice shows a positive trend in observational data (Kwok et al., 2009; Maslanik et al., 2007). The decrease in sea ice area and mean sea ice thickness results in a reduction of sea ice volume, which is supported by model simulations. The relative reduction of sea ice volume is stronger than the sea ice area retreat (Gregory, 2002). According to the Pan-Arctic Ice-Ocean Modeling and Assimilation System (PIOMAS), the September 2010 ice volume anomaly, for instance, did in fact exceed the previous 2007 minimum by a large enough margin to establish a statistically significant new record (Schweiger et al., 2011).

Most studies to date focused on the changes in the entire Arctic. Here, we examine sea ice changes of smaller regions in relation to the entire Arctic. As shown by Overland et al. (1997) the climate changes in the Arctic considerably differ between individual regions. Some regions may be of particular importance for the Arctic climate variability such as the Barents Sea. Strong variability of oceanic inflow, intense heat losses from the sea surface and possible positive feedbacks in the regional coupled

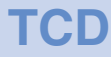

$6,5317-5344,2012$

\section{The Arctic Sea ice in the CMIP3 climate model ensemble}

L. K. Behrens et al.

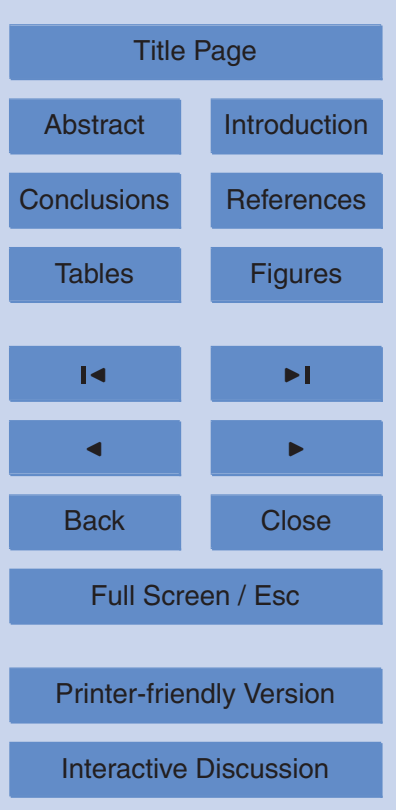


atmosphere-sea ice-ocean system lead to enhanced climate variations in this region that affect the whole-Arctic climate (Bengtsson et al., 2004; Semenov and Bengtsson, 2003; Semenov, 2008; Semenov et al., 2009). The sea ice extent in the Barents Sea is also impacted by the North Atlantic Oscillation (NAO) (Kwok, 2000), the leading mode 5 of internal atmospheric variability in the northern Extratropics during winter. A negative NAO phase yields an anomalous sea ice transport into the Barents Sea, whereas a positive NAO phase transports more sea ice from the Barents Sea into the Arctic Ocean. The sea ice conditions in the Barents Sea are also influenced by the North Atlantic Current (Gloersen et al., 1992) and, possibly, by the Atlantic Multidecadal Os10 cillation (Semenov, 2008). The oceanic inflow into the Barents Sea is also impacted by the NAO, and the link between all these processes may be non-stationary as suggested by climate models (Goosse and Holland, 2005; Semenov, 2008). Petoukhov and Semenov (2010) suggest that a reduced sea ice extent changes in the BarentsKara Sea region may exert a strong effect on the European climate through changes 15 in atmospheric circulation leading to anomalously cold winters over Eurasia. Thus, the Barents Sea is one focus region of our analyses. The Central Arctic is another region of interest, because this region is covered nearly all year round by sea ice in the preindustrial control integrations of the climate models.

The models considerably differ not only in the simulated sea ice behaviour but also concerning the rates of global warming. Whether the differences in the simulated sea ice changes are related to the different warming pace or represent regional and sea ice related model uncertainties remains an open question. Therefore, we assess the sensitivity of sea ice changes to warming in the individual Arctic regions in each model as well as the differences between the models.

25 We also study the amplitude and phase of the sea ice seasonal cycle. The latter characterizes the sharpness of the seasonal contrasts and is an important parameter for evaluating climate impacts. In particular, a shortened ice season may lead to considerable advantages for marine transportation using Northern Sea Route and North-West Passage (Khon et al., 2010). Furthermore, changes in sea ice area and thickness in

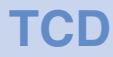

$6,5317-5344,2012$

\section{The Arctic Sea ice in the CMIP3 climate model ensemble}

L. K. Behrens et al.

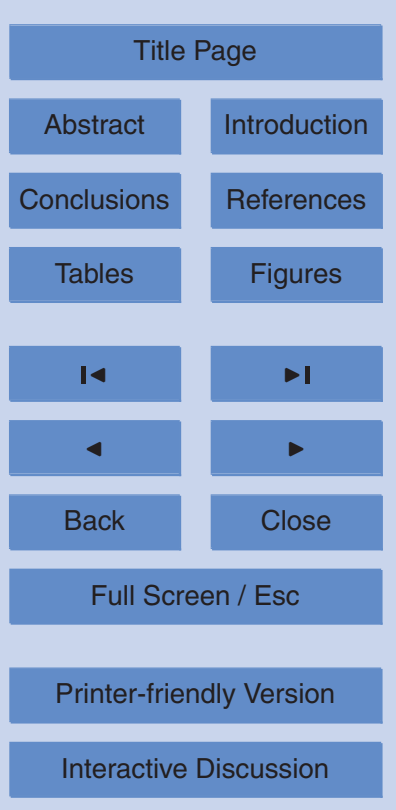


the Arctic basin are accompanied by changes in the variability (Holland et al., 2008). We investigate the interannual variability in all CMIP3 models. The main question is how the interannual sea ice variability may change in a warmer climate.

The paper is organized as follows. In the next section, we provide a description of 5 the data sets which are used in this study. In section three, the results are presented. The main conclusions and a discussion of the results can be found in section four.

\section{Data and methods}

The analysis is based on the World Climate Research Programme's (WCRP's) Coupled Model Intercomparison Project phase 3 (CMIP3) multi-model dataset covering the 10 period 1900-2100 (see Table 1). Additionally, the observational data set HadISST1 (Rayner et al., 2003) providing sea surface temperature (SST) and sea ice extent since 1870 for comparison (see Table 1). Specifically, 20C3M runs for the 20th century complemented by climate change simulations using A1B-scenario for the 21 st century were analysed. We also investigate the preindustrial control runs. Only the first member of each climate model ensemble is used, since models have different number of ensemble simulations, some of them just one. Observational and model data were interpolated onto a $2^{\circ} \times 2^{\circ}$ grid for inter comparison.

Sea ice area and sea ice volume are calculated as follows. The sea ice area is defined as averaged ice concentration multiplied by grid box size. Accordingly, the sea ice volume is defined as sea ice thickness multiplied by sea ice area.

In the following, we present results for the entire Arctic, the Central Arctic and the Barents Sea. One should keep in mind that model differences can result from the different initial conditions and different horizontal resolutions of the land masks. For example, smaller islands like Svalbard are not resolved in some models. Models with a coarse coastline resolution are marked with an asterisk in Table 1.

The Arctic Sea ice in the CMIP3 climate model ensemble

L. K. Behrens et al.

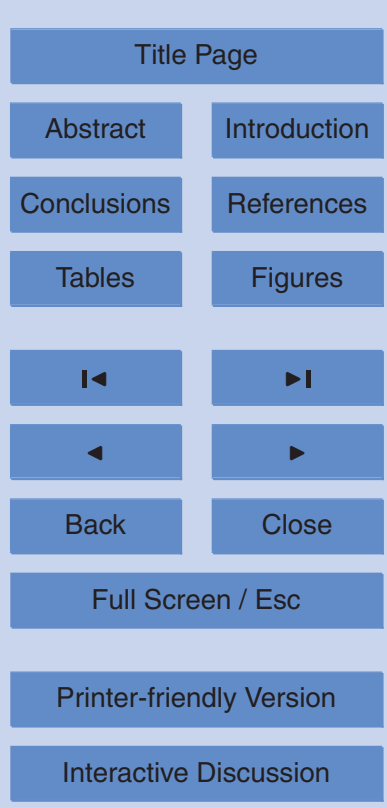


The Central Arctic is defined as a basin north of $80^{\circ} \mathrm{N}$. The Barents Sea is defined as an area between $70^{\circ} \mathrm{N}$ (Russian coast) and $80^{\circ} \mathrm{N}$ and between $20^{\circ} \mathrm{E}$ (Svalbard) and $62^{\circ} \mathrm{E}$ (Novaya Zemlya) (see Gloersen et al., 1992).

The amplitude and the phase of the seasonal cycle are calculated with the Fourier 5 approach of Granger and Hatanaka (1964). The time series have been detrended prior to the calculation of the annual harmonic of the monthly mean sea ice data.

\section{Results}

Figure 1 shows the observed and simulated (for the ensemble mean) interannual variability of the sea ice concentration. The observations (Fig. 1a, b) reveal that the inter10 annual variability is largest in the regions close to the ice edge during winter (March). In summer (September), the areas of high interannual variability move with the seasonal sea ice edge into the Central Arctic Basin. The model data are shown as an overall mean of the interannual variability of the sea ice concentration of each ensemble member (models included here according to Table 1). The sea ice interannual variabil15 ity pattern of the preindustrial (Fig. 1c, d) and the 20th century (Fig. 1e, f) simulations are similar. However, multi-model mean for the 20th century simulations (Fig. 1e, f) overestimates the interannual variability in many regions in comparison to the observations (Fig. 1a, b). In winter, the area of high interannual variability is generally larger in the models (Fig. 1a, e). In the Barents Sea, the strong interannual variability region 20 extends too much to the southwest. We also would like to note the large differences in the Bering Sea and Sea of Okhotsk. In summer, the models exhibit a more symmetric interannual variability around the Arctic Ocean, whereas the observations show stronger variability near the Russian coast and less variability near Canada (Fig. 1b, f).

The spatial pattern of the interannual variability is different in the 21 st century. 25 Changes in variability for the 2050-2100 period relative to the 1950-2000 period are located along the ice edge and in regions of strong sea ice retreat (Fig. $1 \mathrm{~g}$, i). An enhancement of the inter-annual variability is obvious in the Central Arctic. These

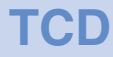

$6,5317-5344,2012$

\section{The Arctic Sea ice in the CMIP3 climate model ensemble}

L. K. Behrens et al.

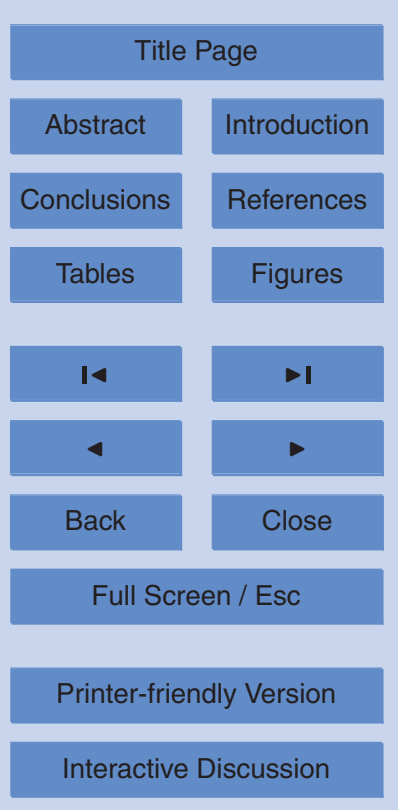


changes are most noticeable during September (Fig. 1k). The strongest interannual variability during September for the period 2050-2100 is now located in the centre of the Arctic basin, whereas in the preindustrial simulations, the maximum can be found in coastal regions (Fig. 1d, h).

\section{3.1 Changes in Arctic sea ice area and sea ice volume}

The sea ice area anomalies have a strong impact on the ocean heat budget due to changes in albedo and thus insulation, whereas the changes in the ice volume are of major importance for the surface salinity budget. Changes in sea ice area and sea ice volume are shown in Fig. 2 for the entire Arctic. The multi-model mean depicts 10 a continuous reduction of both parameters until the end of the century in all seasons. The sea ice area decease is stronger in September than in March (Fig. 2a, b). In March, there is a decrease of about $4 \times 10^{6} \mathrm{~km}^{2}$ in the multi-model mean by the end of the $21 \mathrm{st}$ century. In September, the decrease reaches about $5 \times 10^{6} \mathrm{~km}^{2}$. Similar values have been reported by Meehl et al. (2007). Figure 2c, d shows the sea ice volume anomalies 15 relative to $1970-2000$. There is a decrease of about $17 \times 10^{3} \mathrm{~km}^{3}$ in March and about $13 \times 10^{3} \mathrm{~km}^{3}$ in September. In contrast to the ice area changes, we found a stronger decrease of the ice volume in September.

The multi-model mean decrease of the sea ice area in March has nearly the same rate as observed for the entire Arctic during the overlapping period (see Fig. 3a). How20 ever, the decrease in sea ice area during September is stronger in the observational data than in the multi-model mean (see Fig. 3b). This was previously found by Stroeve et al. (2007). The Arctic sea ice area decline exhibits strong regional variations. We therefore compare the models with the data for selected regions. In all seasons, a better agreement between the models and observations can be found in the Central Arctic

25 (Fig. 3c, d). Consistent with the empirical data, the models simulate a strong decrease in this region in September. In the Barents Sea, the multi-model mean sea ice area considerably departs from the observations (Fig. 3e, f). The multi-model mean predicts almost the same rate of sea ice area reduction during March and September, with much 5323

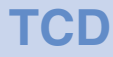

$6,5317-5344,2012$

The Arctic Sea ice in the CMIP3 climate model ensemble

L. K. Behrens et al.

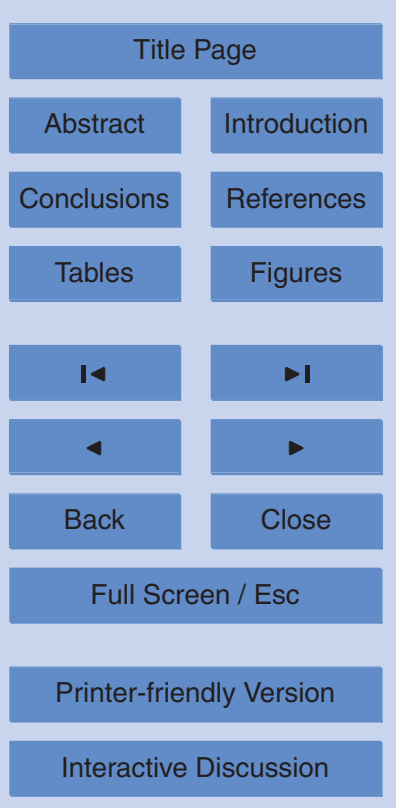


smaller absolute sea ice area values in September. While the rate of change is underestimated by the models in March, it is consistent with the observed rate in September. The most striking difference to the observations is the much too large sea ice area in the Barents Sea simulated on average by the models. The difference between the ob5 servations and multi-model mean is considerably larger in the Barents Sea than for the entire Arctic, whereas the Central Arctic shows a realistic sea ice area. In the Central Arctic, a decrease sea ice area in summer is found in all model runs and in the observations. In winter, virtually no changes are noticeable neither in the observations nor in the models until the middle of the 21st century (Fig. 3c, d).

\subsection{Sensitivity of sea ice area to atmospheric temperature changes}

Are the model differences related to different rates of global warming, to different sensitivities of the sea ice to warming or to both? We analyze the sensitivity of the sea ice area to changes in Northern Hemisphere surface air temperature using the periods 1970-2000 and 2070-2100. The scatter diagrams in Figs. 4 and 5 show the sensi15 tivities for the individual models in the three selected regions during winter (January, February, March) and summer (July, August, September), respectively. The sea ice area changes are regressed upon Northern Hemisphere average surface air temperature anomalies.

For the entire Arctic sea ice area, a linear dependence of the winter sea ice area on the Northern Hemisphere temperature change can be seen (see Fig. 4a), with a correlation coefficient amounting to -0.85 and a slope of the regression line of $-2 \times 10^{6} \mathrm{~km}^{2}{ }^{\circ} \mathrm{C}^{-1}$. No linear relation is seen in the Central Arctic (Fig. 4b). This is consistent with Fig. $3 \mathrm{c}$ which shows a large model spread in the sea ice area in March until the end of the century, ranging from a weak increase to a very strong decline. 25 This explains the lack of a linear relation in Fig. 4b. Finally, the Barents Sea (Fig. 4c) features a statistically significant correlation between sea ice area and Northern Hemisphere surface air temperature changes that amounts to -0.64 with a regression of $-2 \times 10^{5} \mathrm{~km}^{2}{ }^{\circ} \mathrm{C}^{-1}$.

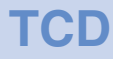

$6,5317-5344,2012$

\section{The Arctic Sea ice in the CMIP3 climate model ensemble}

L. K. Behrens et al.

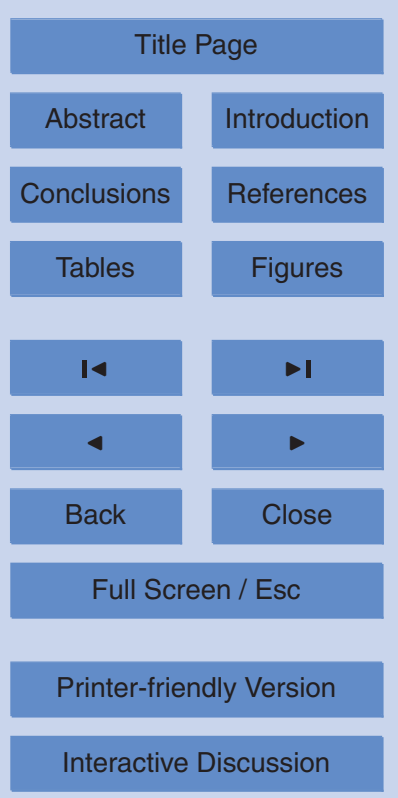

Interactive Discussion 
The summer sensitivities (Fig. 5) exhibit several noticeable differences in comparison to those obtained for winter. The strongest correlation $(-0.66)$ is now retrieved for the Central Arctic (Fig. 5b) with a regression of $-0.7 \times 10^{6} \mathrm{~km}^{2}{ }^{\circ} \mathrm{C}^{-1}$. This correlation is even higher than that obtained for the entire Arctic (Fig. 5a) which showed 5 the strongest correlation in winter. The entire Arctic is characterized by a correlation -0.57 and a regression of $-1 \times 10^{6} \mathrm{~km}^{2}{ }^{\circ} \mathrm{C}^{-1}$. This is also weaker than winter value. Obviously, the sea ice area in the Central Arctic is more sensitive to temperature than the entire Arctic in summer. The Barents Sea (Fig. 5c) sea ice area does not show any linear dependence on the Northern Hemisphere temperature change in summer, 10 which may suggest that ocean dynamical feedbacks play an important in this region.

\subsection{Changes in the amplitude and phase of the seasonal cycle}

The large decrease in sea ice area during September and weaker reduction in winter imply that the amplitude of the annual cycle will increase (Fig. 6a, b). This is seen in the observations in the entire Arctic (Fig. 6a) and the Central Arctic (Fig. 6c), but not 5 in the Barents Sea (Fig. 6e). At the end of the 20th century, the amplitude of seasonal sea ice area cycle in the entire Arctic for the model ensemble mean is $5.0 \times 10^{6} \mathrm{~km}^{2}$, which consists of about $40 \%$ of the maximum winter sea ice area. Until the end of the $21 \mathrm{st}$ century, the amplitude increases to $5.5 \times 10^{6} \mathrm{~km}^{2}$ in the models on average, which amounts to $50 \%$ of the maximum sea ice area. Therefore, the increase of the amplitude of the sea ice area seasonal cycle may serve as a good indicator of the portion of new ice freezing during winter. The observations suggest a somewhat stronger amplification of the seasonality than the CMIP3 multi-model mean for the entire Arctic.

The CMIP3 models project a steeper increase in the amplitude of the sea ice area annual cycle in the Central Arctic (Fig. 6c) compared to that in the entire Arctic (Fig. 6a). 25 From the beginning to the end of the 21 st century, the ratio between sea ice area annual cycle amplitude to the maximum winter area (for the multi-model mean) increases from about 0.1 to 0.4 , with the amplitude of $0.9 \times 10^{6} \mathrm{~km}^{2}$ in 2100 . During the recent decades, the observations and the multi-model mean show a consistent amplitude

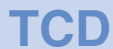

$6,5317-5344,2012$

\section{The Arctic Sea ice in the CMIP3 climate model ensemble}

L. K. Behrens et al.

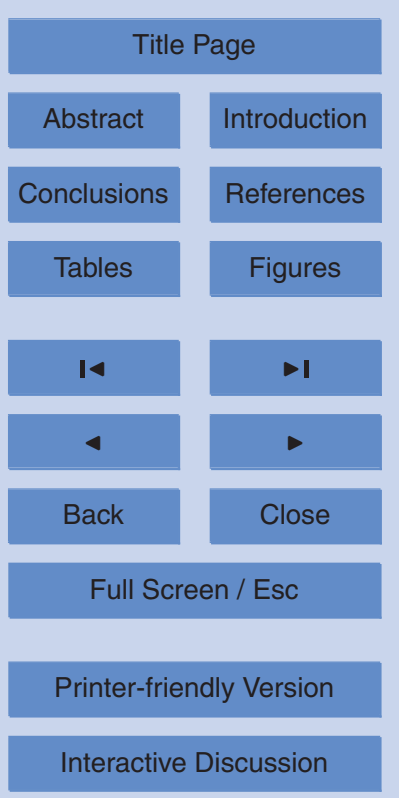

Interactive Discussion 
increase for the Central Arctic. It should be noted that the model spread is large and becomes even stronger toward the end of the 21st century (Fig. 6c). The amplitude of the sea ice area seasonal cycle in the Barents Sea exhibits a different behavior. The projections do not show any significant changes in amplitude for the multi-model mean 5 (Fig. 6e), due to similar rates of sea ice area decrease during March and September (see Fig. 3e, f). Again, the model spread is large and may exhibit opposite tendencies. The observations indicate a reduction in the amplitude of the sea ice area annual cycle in the Barents Sea, but with strong variability superimposed. Strong decadal to inter-decadal variability in the Barents Sea is also simulated by most models, which is 10 consistent with the notion that the Barents Sea is a region which is strongly affected by variations of oceanic inflow.

The phase of the seasonal cycle during the 20th and 21st century also exhibits interesting features in the considered regions. The multi-model mean for the entire Arctic shows a phase shift of about 5 days from year 2000 until year 2100 . The observations do not show a long-term trend, but a strong decadal variability. The simulated multimodel estimate of the phase corresponds well to the mean observed phase (Fig. 6b). This is not the case for the Central Arctic, where the observed phase of the annual cycle exceeds the model average by some 7 days (Fig. $6 \mathrm{~d}$ ). The simulated multi-model mean increase of the phase amounts to about 15 days in the Central Arctic by the end of the century. A similar phase shift of about 10 days can be found in the Barents Sea (Fig. 6f). Again, we see very strong differences between the individual models in all regions. The models depict decadal variability of the phase similar to that observed in the Central Arctic, but considerably less decadal variability in the entire Arctic and the Barents Sea.

25 We now turn to the seasonal cycle changes of the sea ice volume (Fig. 7). Unfortunately, reliable observations of sea ice volume are not available for the last decades due to the lack of sea ice thickness measurements. The simulated multi-model mean sea ice volume exhibits stronger losses in March than in September when considering the entire Arctic, as shown above (see Fig. 3). This is reflected by a corresponding

\section{TCD}

$6,5317-5344,2012$

\section{The Arctic Sea ice in the CMIP3 climate model ensemble}

L. K. Behrens et al.

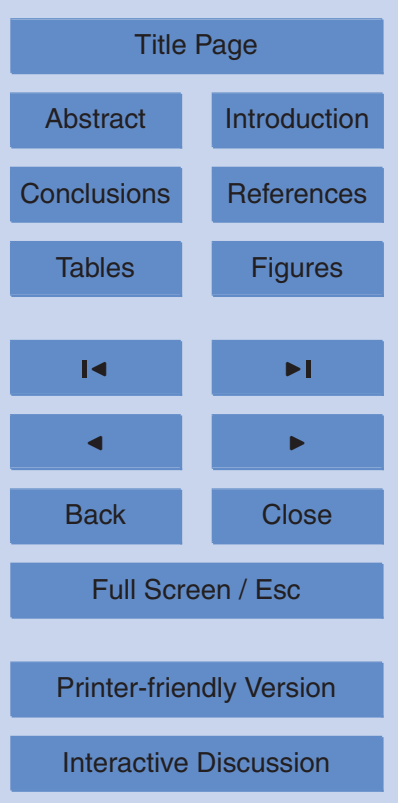

Interactive Discussion 
decrease of the seasonal cycle amplitude of the sea ice volume by about $2 \times 10^{4} \mathrm{~km}^{3}$ (Fig. 7a) during the 21st century in this region. Concerning the entire Arctic, nearly all models simulate a long-term decrease. The simulated phase of the sea ice volume seasonal cycle (Fig. $7 \mathrm{~b}$ ) remains very stable in the vast majority of the models during 5 the 20th and 21st century. The amplitude of the sea ice volume seasonal cycle shows a different behavior in the Central Arctic (Fig. 8a). Here, the amplitude of the seasonal cycle on average increases until the middle of the 21 st century due the strong reduction in the summer sea ice area. In the second half of the 21st century, some models predict the ice free Arctic in summer, which leads to a reduction of the multi-model mean amplitude of the sea ice volume seasonal cycle. By the end of the 21 st century, the amplitude of the seasonal cycle has basically returned to the values simulated during the 20th century (Fig. 8a). In the Barents Sea, most models simulate a decrease of the sea ice area in winter but a stronger decline during summer. This leads to a reduction in the sea ice volume seasonal cycle amplitude in most of the model projections for the 21st century (Fig. 8b). The sea ice volume seasonal cycle phase shows no valuable shift for both region (not shown).

\subsection{Changes in variability}

Climate change influences not only the annual mean and the seasonal cycle of Arctic sea ice but also its interannual variability. Changes in interannual variability will affect the sea ice predictability and occurrence of extreme anomalies of the sea ice area. We analyze the standard deviation of the sea ice area for the following three time periods: preindustrial (using the results of the control simulations), 1950-2000 and 2050-2100. The long-term trend has been subtracted as a fourth order polynomial fit. Figure 9 shows interannual sea ice area variability in each model for March and September. During the preindustrial period, most models simulate a stronger interannual variability in March compared to that in September (Fig. 9a). Only minor changes can be seen for the 1950-2000 period (Fig, 9b). The simulated values for this time period can be

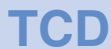

$6,5317-5344,2012$

\section{The Arctic Sea ice in the CMIP3 climate model ensemble}

L. K. Behrens et al.

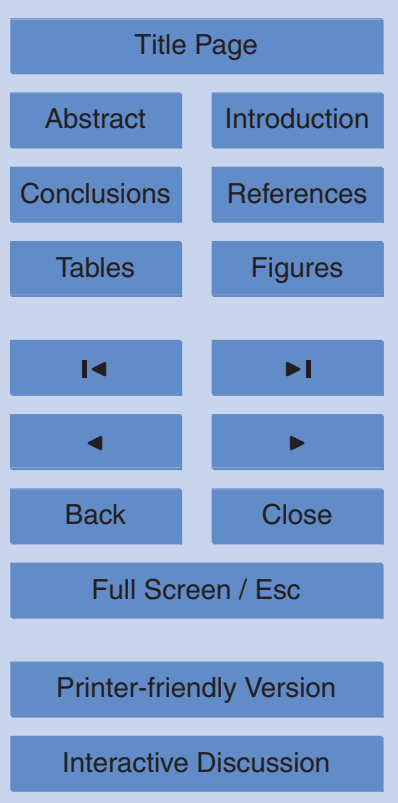


compared to the observations (Fig. 9b). The latter depict a stronger variability during September, which is also the case for the majority of the models.

During the second half of the 21st century, the number of the models which simulate a stronger interannual variability during September relative to that in March markedly 5 increases (Fig. 9c). The tendency of enhanced interannual variability for summer sea ice area t may serve as a fingerprint of anthropogenically forced Arctic sea ice changes. One possible explanation for the projected changes in the sea ice variability may be the changes in sea ice thickness. A link between the sea ice area variability during September and the sea ice thickness in March has been found in the preindustrial 10 control runs, such that those models that exhibit a higher variability during September generally show a smaller mean sea ice thickness in March (Fig. 10a), with a correlation coefficient amounting to -0.68 . This relationship is almost lost in the projections for 2050-2100 (Fig. 10b).

We investigate the significance of the change in the interannual variability between 15 the preindustrial period and the period 2050-2100. According to an one sided F-test, 8 out of 15 models show a statistically significant ( $95 \%$ confidence level) reduction in March, while two models project a significantly higher variability for the period 20502100. For September, the month of the sea ice minimum, 9 out of the 15 models show a significant enhancement of the interannal variability of the sea ice area during 20502100 compared to the preindustrial era, whereas four models predict a reduction of the interannual variability. Thus there is a tendency that the models simulate higher variability during September than in March toward the end of the 21st century, while the models show a higher variability during March in the preindustrial control runs.

\section{Discussion and conclusion}

25 The CMIP3 ensemble integrations for the 20th century and 21st century using the A1B scenario provide a wide range of changes in the Arctic sea ice cover. The multimodel mean results are generally close to observations during the recent decades.

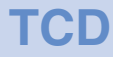

$6,5317-5344,2012$

\section{The Arctic Sea ice in the CMIP3 climate model ensemble}

L. K. Behrens et al.

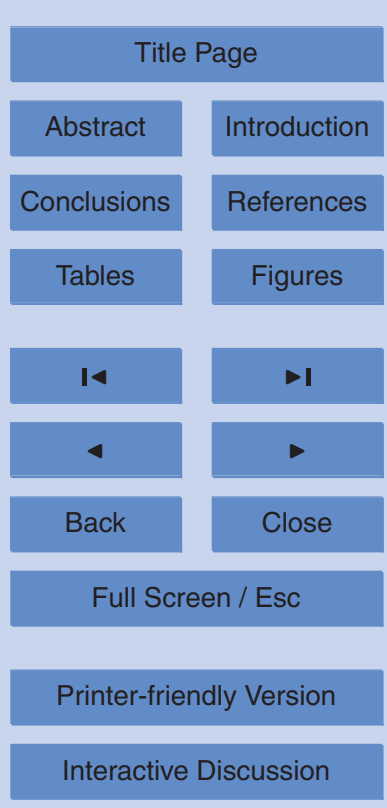


The projected decrease in the Arctic sea ice cover is closely linked to the increase of the Northern Hemisphere average surface air temperature (SAT) and especially to the increase of the Arctic SAT. The latter is projected to warm twice as strong by the end of the 21st century than the global average SAT (Anisimov et al., 2007). Due to 5 positive feedbacks, the decrease in sea ice area during September was and will be stronger than during March. The winter sea ice retreat shows a stronger sensitivity $\left(-2 \times 10^{6} \mathrm{~km}^{2}{ }^{\circ} \mathrm{C}^{-1}\right)$ to the Northern Hemisphere average SAT than the summer sea ice $\left(-1 \times 10^{6} \mathrm{~km}^{2}{ }^{\circ} \mathrm{C}^{-1}\right)$. This indicates that the SAT is the leading predictor for the winter sea ice. We find a less strong relationship between the SAT and sea ice area 10 for the Barents Sea. This suggests that dynamical processes also contribute to the variations of the sea ice cover. In particular, the Barents Sea is strongly influenced by the NAO (Kwok, 2000) and Atlantic inflow (Semenov, 2008), both exhibiting strong natural variability on different time scales. This may be also the reason for why the models show stronger differences to the observations during the recent decades.

15 Changes in the seasonal cycle of the sea ice area and sea ice volume have been analyzed. The sea ice area shows an increase in amplitude and shift in phase of the seasonal cycle for the majority of the models and basically all regions. This is related to the faster summer sea ice retreat relative to that in winter. The shift in phase is due to the delayed occurrence of the sea ice area maximum, which can be explained by the strong sea ice area decline during September. Changes are also found for the occurrence of the sea ice area minimum which persists longer, especially in the Central Arctic. The sea ice volume decreases more in winter than in summer, which leads to a reduced seasonal cycle amplitude. The multi-model mean sea ice volume shows practically no change in phase. This is explained by the sea ice thickness which does not show a clear signal in phase (not shown). The observed sea ice area exhibited strong decadal variability during 1960-2011, but no change in phase could be detected when considering the whole period. Gloersen and Campbell (1988) found a change of 24 days for the date of the Arctic sea ice area minimum from 1978 to 1987 . Consistent with their findings, we find a phase shift of about 20 days for the same period.

\section{The Arctic Sea ice in the CMIP3 climate model ensemble}

L. K. Behrens et al.

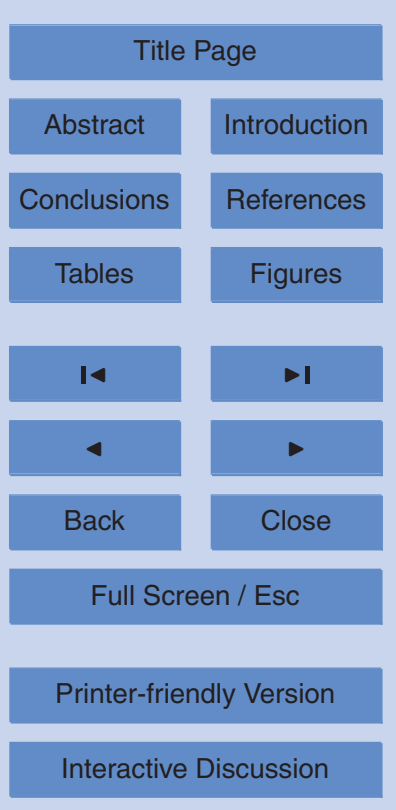


Interannual sea ice area variability exhibits some interesting changes in the CMIP3 simulations when considering the entire Arctic. The interannual variability of the sea ice area during September increases from the preindustrial time until the end of the 21 st century in the majority of the CMIP3 models. The interannual variability generally 5 decreases in March. Enhanced sea ice area variability during September has been also reported from observations by Holland et al. (2008), Holland and Stroeve (2011) and Goosse et al. (2009).

Holland et al. (2008) argued that thinner September sea ice melts faster, but can also faster converge and form big areas. Goosse et al. (2009) also argued that the in10 creasing interannual sea ice area variability in September is related to thinner sea ice. Holland and Stroeve (2011) suppose less impact of the atmospheric circulation on the September sea ice variability because of a shift in the surface pressure (SLP) anomalies in the eastern Arctic. We found a relationship between the September interannual sea ice area variability and the March sea ice thickness in the preindustrial control runs. Models with a thinner mean sea ice thickness during March simulate a higher interannual variability in sea ice area during September. However, this relation could not be found at the end of the 21st century when the sea ice cover is much thinner.

We may conclude that the models forced by increasing greenhouse gas concentrations simulate not only coherent decline of the Arctic mean sea ice area and volume but also exhibit consistent changes of the seasonal cycle characteristics and interannual variability. However, regional changes are characterized by much higher uncertainties. This is particularly the case for the Barents Sea ice that is strongly influenced by natural oceanic and atmospheric variability.

Acknowledgements. We acknowledge the modelling groups, the Program for Climate Model 25 Diagnosis and Intercomparison (PCMDI), the WCRP's Working Group on Coupled Modelling (WGCM) for their roles in making available the WCRP CMIP3 multi-model dataset, and we thank the climate modeling groups (listed in Table 1 of this paper). Support of this dataset is provided by the Office of Science, US Department of Energy. This work was supported by the North Atlantic Project of BMBF and the European Union's THOR project. V.A. Semenov was also supported by the Russian Foundation for Basic Research (11-05-00579a) and Presidium

5330

\section{6, 5317-5344, 2012}

\section{The Arctic Sea ice in the CMIP3 climate model ensemble}

L. K. Behrens et al.

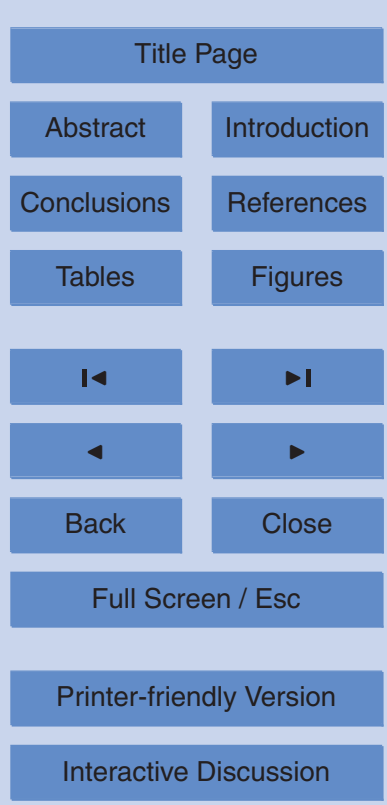

Interactive Discussion 
The service charges for this open access publication have been covered by a Research Centre of the

\section{References}

Alekseev, G. V., Kuzmina, S. I., Nagurny, A. P., and Ivanov, N. E.: Arctic sea ice data sets in the context of climate change during the 20th century, climate variability and extremes during the past 100 years, Adv. Glob. Change Res., 33, 47-63, 2007.

10 Alekseev, G. V., Danilov, A. I., Kattsov, V. M., Kuz'mina, S. I., and Ivanov, N. E.: Changes in the climate and sea ice of the Northern Hemisphere in the 20th and 21st centuries from data of observations and modeling, Izv. Atmos. Ocean. Phy.+, 45, 675-686, doi:10.1134/S0001433809060012, 2009.

Anisimov, O. A., Vaughan, D. G., Callaghan, T., Furgal, C., Marchant, H., Prowse, T. D., Vilhjalmsson, H., and Walsh, J. E.: Polar regions (arctic and antarctic), in: Climate Change 2007: Impacts, Adaptation and Vulnerability. Contribution of Working Group II to the Fourth Assessment Report of the Intergovernmental Panel on Climate Change, edited by: Parry, M., Canziani, O., Palutikof, J., van der Linden, P., and Hanson, C., chap. 15, Cambridge University Press, Cambridge, 653-685, 2007.

Bengtsson, L., Semenov, V. A., and Johannessen, O. M.: The early twentieth-century warming in the arctic - a possible mechanism, J. Climate, 17, 4045-4057, 2004.

Gloersen, P. and Campbell, W. J.: Variations in the Arctic, Antarctic, and global sea ice covers during 1978-1987 as observed with the Nimbus7 scanning multichannel microwave radiometer, J. Geophys. Res., 93, 666-674, 1988.

25 Gloersen, P., Campbell, W. J., Cavalieri, D. J., Comiso, J. C., Parkinson, C. L., and Zwally, J. H.: Arctic and Antarctic Sea Ice, 1978-1987: Satellite Passive-Microwave Observartions and Analysis, National Aeronautics and Space Administration, Washington, DC, 1992.

Goosse, H., Arzel, O., Bitz, C. M., de Montety, A., and Vancoppenolle, M.: Increased variability of the Arctic summer ice area in a warmer climate, Geophys. Res. Lett., 36, L23702, doi:10.1029/2009GL040546, 2009.

The Arctic Sea ice in the CMIP3 climate model ensemble

L. K. Behrens et al.

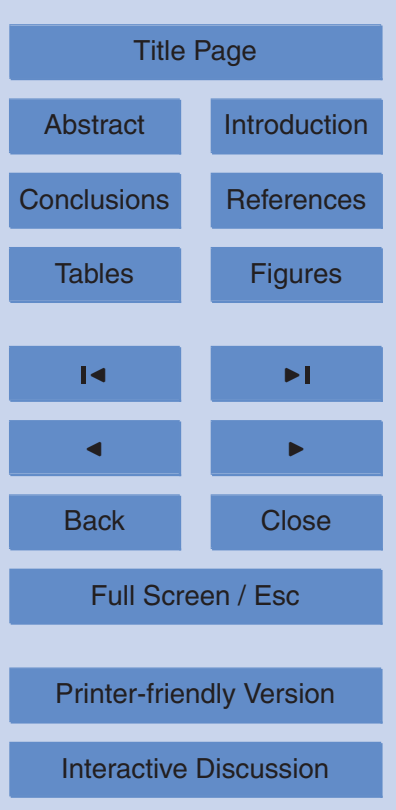

Interactive Discussion 
Goosse, H. and Holland, M. M.: Mechanisms of decadal arctic climate variability in the community climate system model, version 2 (CCSM2), J. Climate, 18, 3552-3570, 2005.

Granger, C. H. J. and Hatanaka, M.: Spectral analysis of economic time series, University Press Princeton, NJ, 1964.

5 Gregory, J. M.: Recent and future changes in Arctic sea ice simulated by the HadCM3 AOGCM, Geophys. Res. Lett., 29, 1999-2002, doi:10.1029/2001GL014575, 2002.

Holland, M. M. and Stroeve, J.: Changing seasonal sea ice predictor relationships in a changing Arctic climate, Geophys. Res. Lett., 38, 1-6, doi:10.1029/2011GL049303, 2011.

Holland, M. M., Bitz, C. M., Tremblay, L., and Bailey, D. A.: The role of natural versus forced change in future rapid summer Arctic ice loss, Arctic sea ice decline: observations, projections, mechanisms, and implications, Geoph. Monog. Series, 180, 133-150, 2008.

Kinnard, C., Zdanowicz, C. M., Fisher, D. A., Isaksson, E., de Vernal, A., and Thompson, L. G.: Reconstructed changes in Arctic sea ice over the past 1450 years, Nature, 479, 509-512, 2011.

Khon, V. C., Mokhov, I. I., Latif, M., Semenov, V. A., and Park, W.: Perspectives of Northern sea route and Northwest Passage in the 21st century, Climatic Change, 100, 757-768, doi:10.1007/s10584-009-9683-2, 2010.

Kwok, R.: Recent changes in Arctic ocean sea ice motion associated with the north Atlantic oscillation, Geophys. Res. Lett., 27, 775-778, 2000.

20 Kwok, R., Cunningham, G. F., Wensnahan, M., Rigor, I., Zwally, H. J., and Yi, D.: Thinning and volume loss of the Arctic Ocean sea ice cover: 2003-2008, J. Geophys. Res., 114, C07005, doi:10.1029/2009JC005312, 2009.

Maslanik, J. A., Fowler, C., Stroeve, J., Drobot, S., Zwally, J., Yi, D., and Emery, W.: A younger, thinner Arctic ice cover: increased potential for rapid, extensive sea-ice loss, Geophys. Res. Lett., 34, 2004-2008, doi:10.1029/2007GL032043, 2007.

Meehl, G. A., Stocker, T. F., Collins, W. D., Friedlingstein, P., Gaye, A. T., Gregory, J. M., Kitoh, A., Knutti, R., Murphy, J. M., Noda, A., Raper, S. C. B., Watterson, I. G., Weaver, A. J., and Zhao, Z.-C.: Global climate projections, in: Climate Change 2007: The Physical Science Basis, Contribution of Working Group I to the Fourth Assessment Report of the Intergovernmental Panel on Climate Change, edited by: Solomon, S., Qin, D., Manning, M., Chen, Z., Marquis, M., Averyt, K., Tignor, M., and Miller, H., chap. 10, Cambridge University Press, Cambridge, UK and New York, NY, USA, 747-845, 2007.

The Arctic Sea ice in the CMIP3 climate model ensemble

L. K. Behrens et al.

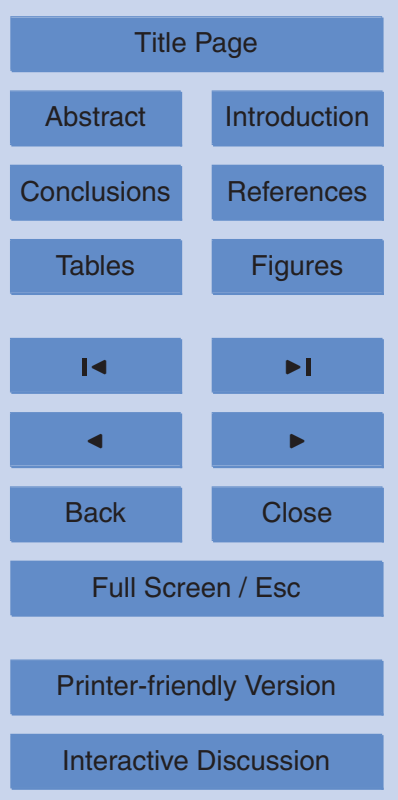


Overland, J. E., Adams, J. M., and Bond, N. A.: Regional variation of winter temperatures in the Arctic, J. Climate, 10, 821-837, 1997.

Petoukhov, V. and Semenov, V. A.: A link between reduced Barents-Kara sea ice and cold winter extremes over northern continents, J. Geophys. Res., 115, D21111, 1-11, doi:10.1029/2009JD013568, 2010.

Rayner, N. A.: Global analyses of sea surface temperature, sea ice, and night marine air temperature since the late nineteenth century, J. Geophys. Res., 108, 4407, doi:10.1029/2002JD002670, 2003.

Schweiger, A., Lindsay, R., Zhang, J., Steele, M., Stern, H., and Kwok, R.: Uncertainty in modeled Arctic sea ice volume, J. Geophys. Res., 116, C00D06, doi:10.1029/2011JC007084, 2011.

Semenov, V. A.: Influence of oceanic inflow to the Barents Sea on climate variability in the Arctic region, Dokl. Earth Sci., 418, 91-94, doi:10.1134/S1028334X08010200, 2008.

Semenov, V. A. and Bengtsson, L.: Modes of the wintertime Arctic temperature variability, Geophys. Res. Lett., 30, 1781, doi:10.1029/2003GL017112, 2003.

Semenov, V. A. and Latif, M.: The early twentieth century warming and winter Arctic sea ice, The Cryosphere, 6, 1231-1237, doi:10.5194/tc-6-1231-2012, 2012.

Semenov, V. A., Park, W., and Latif, M.: Barents Sea inflow shutdown: a new mechanism for climate changes, Geophys. Res. Lett., 36, L14709, doi:10.1029/2009GL038911, 2009.

Stroeve, J., Holland, M. M., Meier, W., Scambos, T., and Serreze, M.: Arctic sea ice decline: faster than forecast, Geophys. Res. Lett., 34, 1-5, doi:10.1029/2007GL029703, 2007.

Stroeve, J. C., Kattsov, V., Barrett, A., Serreze, M., Pavlova, T., Holland, M., and Meier, W. N.: Trends in Arctic sea ice extent from CMIP5, CMIP3 and observations, Geophys. Res. Lett., 39, L16502, doi:10.1029/2012GL052676, 2012.

Wang, M. and Overland, J. E.: A sea ice free summer Arctic within 30 years?, Geophys. Res. Lett., 36, L07502, doi:10.1029/2009GL037820, 2009.

The Arctic Sea ice in the CMIP3 climate model ensemble

L. K. Behrens et al.

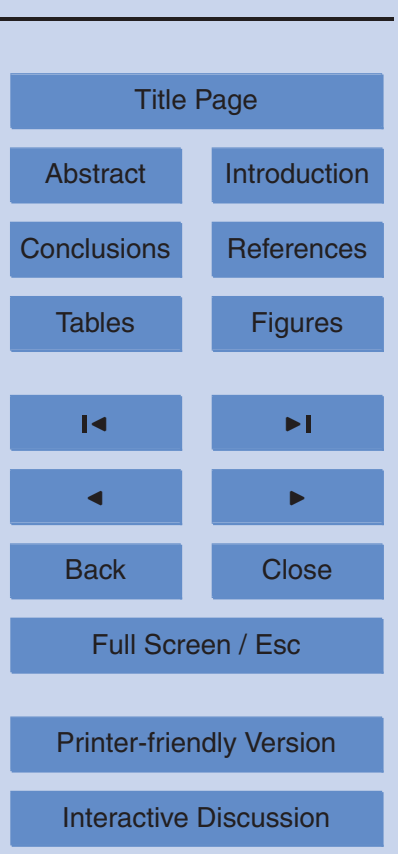


Table 1. CMIP3 Model data set.

\begin{tabular}{|c|c|c|c|}
\hline Model & & $\begin{array}{l}\text { Resolution } \\
\text { Atmosphere }\end{array}$ & $\begin{array}{l}\text { Resolution } \\
\text { Ice }\end{array}$ \\
\hline BCCR-BCM2.0 ${ }^{(1)}$ & $\begin{array}{l}\text { Bjerknes Centre for Climate } \\
\text { Research, Norway }\end{array}$ & $\operatorname{T63}\left(\sim 1.9^{\circ} \times 1.9^{\circ}\right)$ & $1^{\circ} \times 1^{\circ}$ \\
\hline CCCMA-CGCM3.1(T47) & $\begin{array}{l}\text { Canadian Centre for Climate } \\
\text { Modelling and Analysis, Canada }\end{array}$ & $\mathrm{T} 47\left(\sim 2.8^{\circ} \times 2.8^{\circ}\right)$ & $\sim 3.7^{\circ} \times 3.75^{\circ}$ \\
\hline CCCMA-CGCM3.1(T63) ${ }^{(1)}$ & $\begin{array}{l}\text { Canadian Centre for Climate } \\
\text { Modelling and Analysis, Canada }\end{array}$ & $\operatorname{T63}\left(\sim 1.9^{\circ} \times 1.9^{\circ}\right)$ & $\sim 2.7^{\circ} \times 2.8125^{\circ}$ \\
\hline $\mathrm{CNRM}^{-\mathrm{CM}^{(1)}}$ & $\begin{array}{l}\text { Centre National de Recherches } \\
\text { Meteorologiques, France }\end{array}$ & $\operatorname{T63}\left(\sim 1.9^{\circ} \times 1.9^{\circ}\right)$ & $1^{\circ} \times 2^{\circ}$ \\
\hline CSIRO-Mk3.0 $0^{(1)}$ & $\begin{array}{l}\text { Commonwealth Scientific and Industrial } \\
\text { Research Organisation, Australia }\end{array}$ & $\operatorname{T63}\left(\sim 1.9^{\circ} \times 1.9^{\circ}\right)$ & $\sim 1.8^{\circ} \times 1.875^{\circ}$ \\
\hline CSIRO-Mk3.5 $5^{(1)}$ & $\begin{array}{l}\text { Commonwealth Scientific and Industrial } \\
\text { Research Organisation, Australia }\end{array}$ & $\operatorname{T63}\left(\sim 1.9^{\circ} \times 1.9^{\circ}\right)$ & $\sim 1.8^{\circ} \times 1.875^{\circ}$ \\
\hline GFDL-CM2.0 & $\begin{array}{l}\text { Geophysical Fluid Dynamics } \\
\text { Laboratory, USA }\end{array}$ & $2.0^{\circ} \times 2.5^{\circ}$ & $0.3^{\circ}-1^{\circ} \times 1^{\circ}$ \\
\hline GFDL-CM2.1 $1^{(1)}$ & $\begin{array}{l}\text { Geophysical Fluid Dynamics } \\
\text { Laboratory, USA }\end{array}$ & $3^{\circ} \times 4^{\circ}$ & $0.3^{\circ}-1^{\circ} \times 1^{\circ}$ \\
\hline GISS-AOM $^{(1)}$ & $\begin{array}{l}\text { Goddard Institute for Space } \\
\text { Studies, USA }\end{array}$ & $4^{\circ} \times 5^{\circ}$ & $3^{\circ} \times 4^{\circ}$ \\
\hline GISS-MODEL-E-R ${ }^{(1)}$ & $\begin{array}{l}\text { Goddard Institute for Space } \\
\text { Studies, USA }\end{array}$ & $4^{\circ} \times 5^{\circ}$ & $2^{\circ}-4^{\circ} \times 5^{\circ}$ \\
\hline INM-CM3.0 $0^{(1)}$ & $\begin{array}{l}\text { Institute for Numerical } \\
\text { Mathematics, Russia }\end{array}$ & $4^{\circ} \times 5^{\circ}$ & $2^{\circ} \times 2.5^{\circ}$ \\
\hline IPSL-CM4 ${ }^{(1)}$ & Institut Pierre Simon Laplace, France & $2.5^{\circ} \times 3.75^{\circ}$ & $2^{\circ} \times 1^{\circ}$ \\
\hline MIROC3.2(hires) ${ }^{(*)(1)}$ & $\begin{array}{l}\text { Center for Climate System } \\
\text { Research, Japan }\end{array}$ & $\mathrm{T} 106\left(\sim 1.1^{\circ} \times 1.1^{\circ}\right)$ & $\sim 0.5^{\circ} \times 1.125^{\circ}$ \\
\hline MIROC3.2(medres) ${ }^{(*)}(1)$ & $\begin{array}{l}\text { Center for Climate System } \\
\text { Research, Japan }\end{array}$ & $\mathrm{T} 42\left(\sim 2.8^{\circ} \times 2.8^{\circ}\right)$ & $1^{\circ} \times 1^{\circ}$ \\
\hline MPI-ECHAM5 & $\begin{array}{l}\text { Max Planck Institut for } \\
\text { Meteorology, Germany }\end{array}$ & $\operatorname{T63}\left(\sim 1.9^{\circ} \times 1.9^{\circ}\right)$ & $1^{\circ} \times 1^{\circ}$ \\
\hline MRI-CGCM2.3.2A ${ }^{(1)}$ & Meteorological Research Institute, Japan & $\mathrm{T} 42\left(\sim 2.8^{\circ} \times 2.8^{\circ}\right)$ & $0.5^{\circ}-2^{\circ} \times 2.5^{\circ}$ \\
\hline NCAR-CCSM3.0 $0^{(1)}$ & $\begin{array}{l}\text { National Center for Atmospheric } \\
\text { Research, USA }\end{array}$ & $\operatorname{T85}\left(1.4^{\circ} \times 1.4^{\circ}\right)$ & $0.09^{\circ}-0.5^{\circ} \times 1.125^{\circ}$ \\
\hline UKMO-HadCM3 ${ }^{(*)}$ & $\begin{array}{l}\text { Hadley Centre for Climate Prediction } \\
\text { and Research/Met Office, UK }\end{array}$ & $2.5^{\circ} \times 3.75^{\circ}$ & $1.25^{\circ} \times 1.25^{\circ}$ \\
\hline UKMO-HadGEM1 & $\begin{array}{l}\text { Hadley Centre for Climate Prediction } \\
\text { and Research/Met Office, UK }\end{array}$ & $\sim 1.3^{\circ} \times 1.9^{\circ}$ & $0.09^{\circ}-1^{\circ} \times 1^{\circ}$ \\
\hline Observation & Met Office Hadley Centre & & $1^{\circ} \times 1^{\circ}$ \\
\hline
\end{tabular}

The Arctic Sea ice in the CMIP3 climate model ensemble

L. K. Behrens et al.

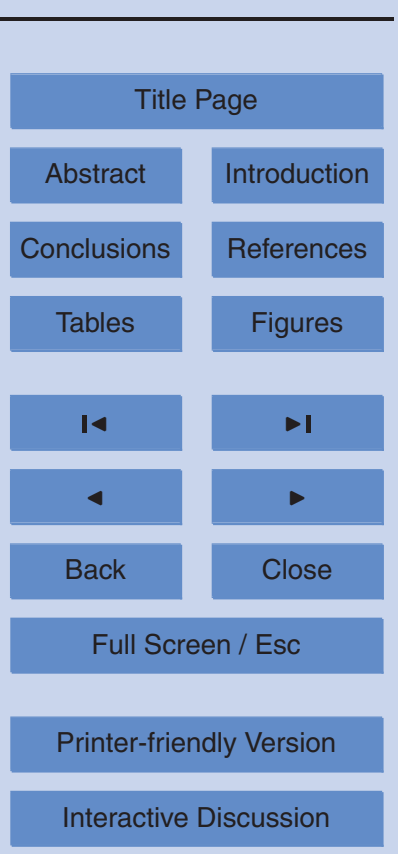

Models marked with ${ }^{(*)}$ do not resolve smaller islands like Svalbard.

Only models marked with ${ }^{(1)}$ do have preindustrial control runs included. 

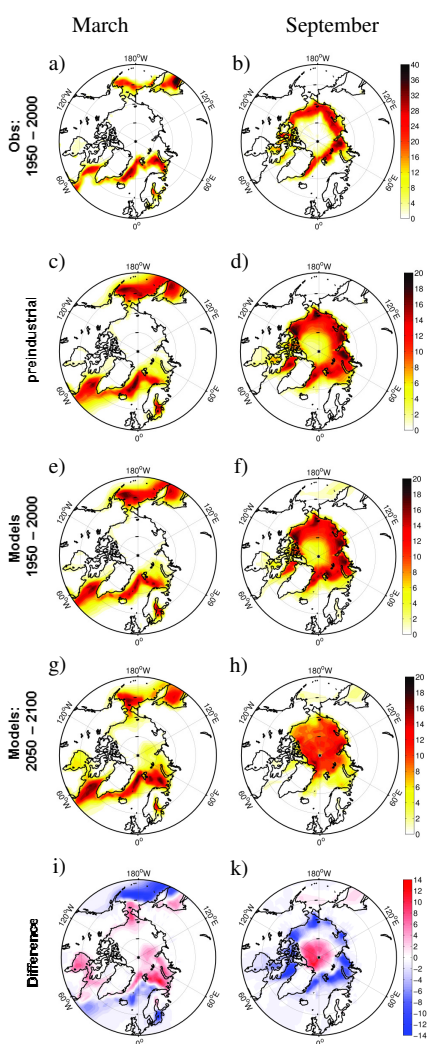

Fig. 1. Interannual sea ice area variability in CMIP3 (models included here are marked by ${ }^{(1)}$ in Table 1); Left: March; Right: September; observation: 1950-2000 (a, b) preindustrial (c, d), 20C3M: 1950-2000 (e, f), SRES A1B: 2050-2100 (g, h) and the differences between SRES $\mathrm{A} 1 \mathrm{~B}$ and preindustrial $(\mathbf{i}, \mathbf{k})$.
TCD

$6,5317-5344,2012$

The Arctic Sea ice in the CMIP3 climate model ensemble

L. K. Behrens et al.

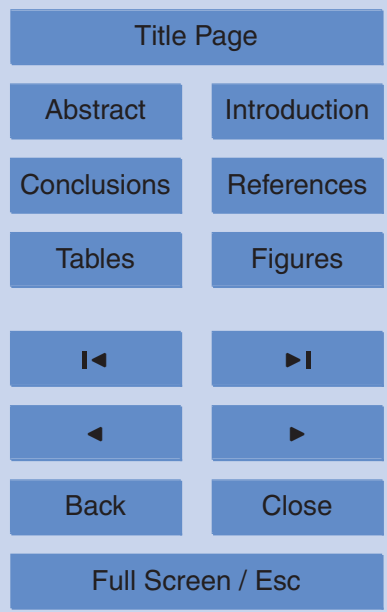

Printer-friendly Version

Interactive Discussion 
a)

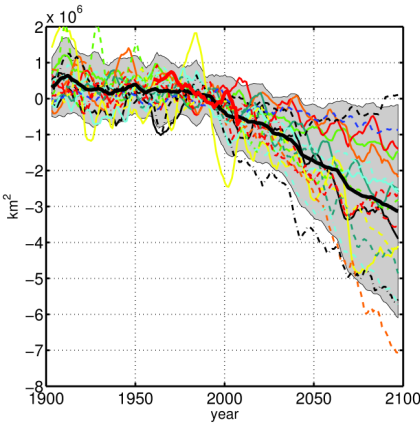

c) b)

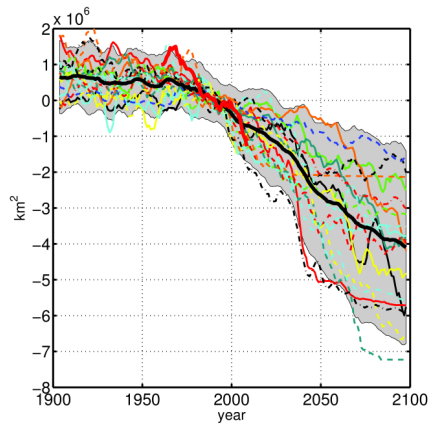

d)

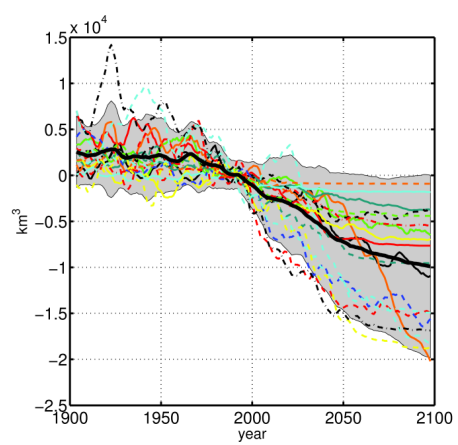

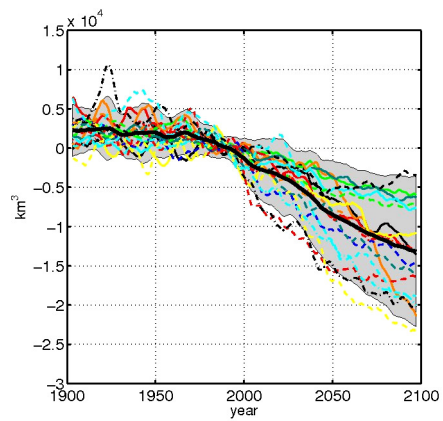

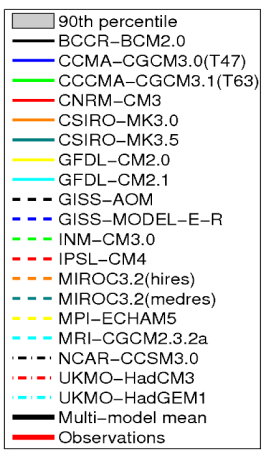

Fig. 2. Sea ice anomalies relative to the years 1970-2000 of the entire Arctic. Sea ice area anomaly (a, b) and sea ice volume anomaly (c, d) in March (left) and in September (right). A five year running mean has been applied. The different models are presented in different colors. The thick black line presents the multi-model mean and the thick red line presents the observations.
The Arctic Sea ice in the CMIP3 climate model ensemble

L. K. Behrens et al.

Title Page

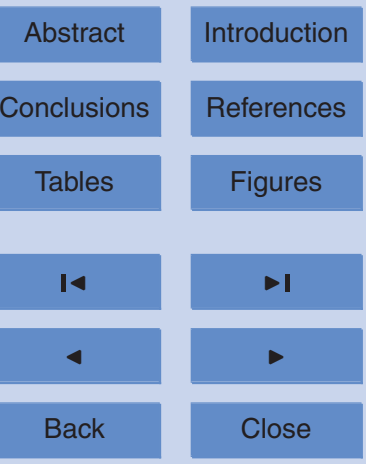

Full Screen / Esc

Printer-friendly Version

Interactive Discussion 
a)

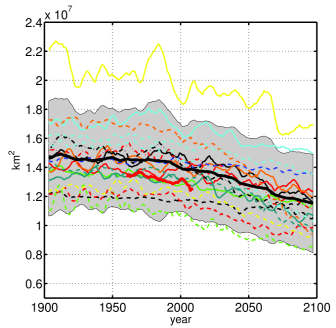

c)

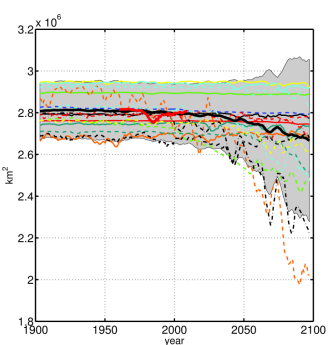

e)

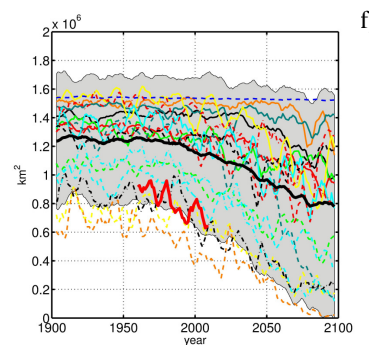

b)

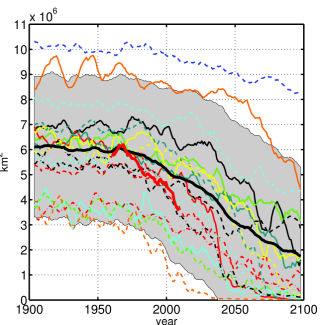

d)

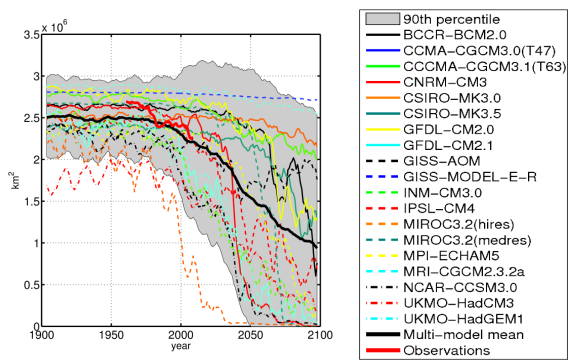

f)

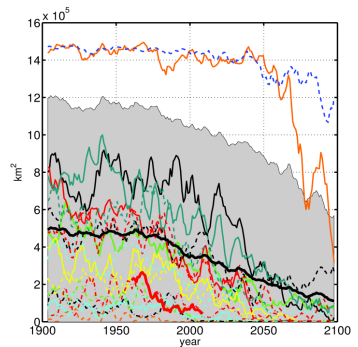

TCD

$6,5317-5344,2012$

The Arctic Sea ice in the CMIP3 climate model ensemble

L. K. Behrens et al.

Title Page

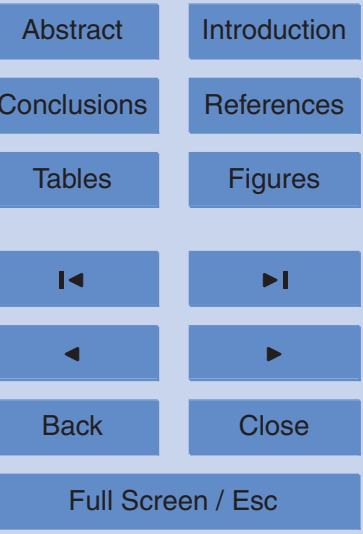

Printer-friendly Version

Interactive Discussion

Arctic (c, d) and the Barents Sea $(\mathbf{e}, \mathbf{f})$. Time series are shown for the March (left) and the September (right) with a five year running mean. The thick black line presents the multi-model mean and the thick red line presents the observations. 
a)

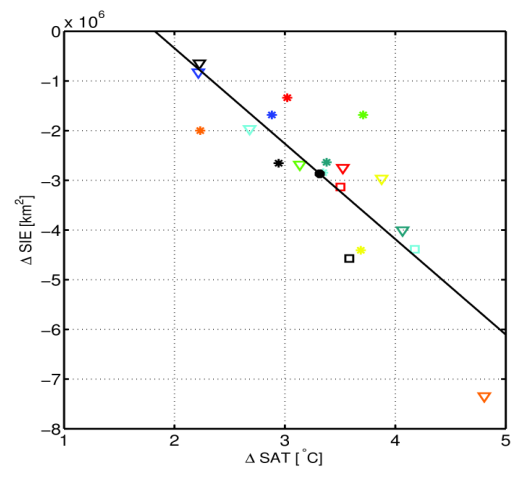

c)

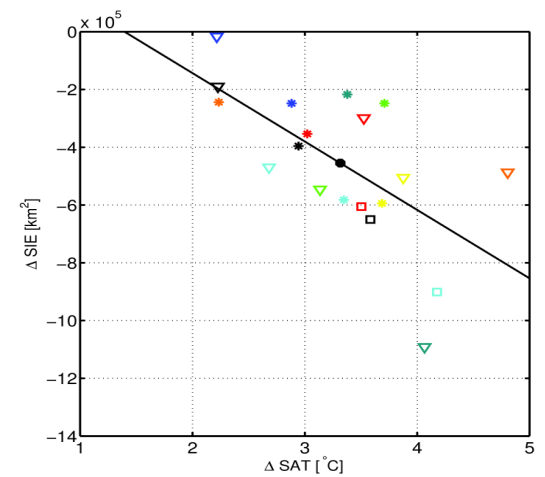

b)

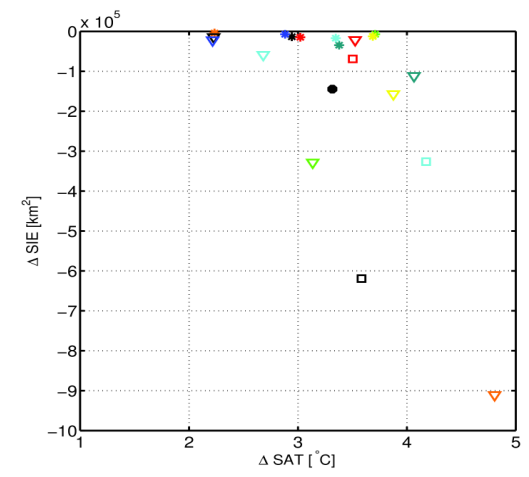

$$
\begin{array}{ll|}
* & \text { BCCR-BCM2.0 } \\
* & \text { CCCMA-CGCM3.0(T47) } \\
* & \text { CCCMA-CGCM3.1(T63) } \\
* & \text { CNRM-CM3 } \\
* & \text { CSIRO-MK3.0 } \\
* & \text { CSIRO-MK3.5 } \\
& \text { GFDL-CM2.0 } \\
* & \text { GFDL-CM2.1 } \\
\nabla & \text { GISS-AOM } \\
\nabla & \text { GISS-MODEL-E-R } \\
\nabla & \text { INM-CM3.0 } \\
\nabla & \text { IPSL-CM4 } \\
\nabla & \text { MIROC3.2(hires) } \\
\nabla & \text { MIROC3.2(medres) } \\
\nabla & \text { MPI-ECHAM5 } \\
\nabla & \text { MRI-CGCM2.3.2a } \\
\square & \text { NCAR-CCSM3.0 } \\
\square & \text { UKMO-HadCM3 } \\
\square & \text { UKMO-HadGEM1 } \\
- \text { Multi-model mean } \\
\hline
\end{array}
$$

Fig. 4. Model sensitivity of the sea ice area of the Arctic against changes in surface air temperature of the Northern Hemisphere between the periods 1970-2000 and 2070-2100 for January, February and March; (a) the entire Arctic (correlation: -0.85), (b) the Central Arctic and (c) the Barents Sea (correlation: -0.64). The line in (a) and (c) is a linear regression.
The Arctic Sea ice in the CMIP3 climate model ensemble

L. K. Behrens et al.

Title Page

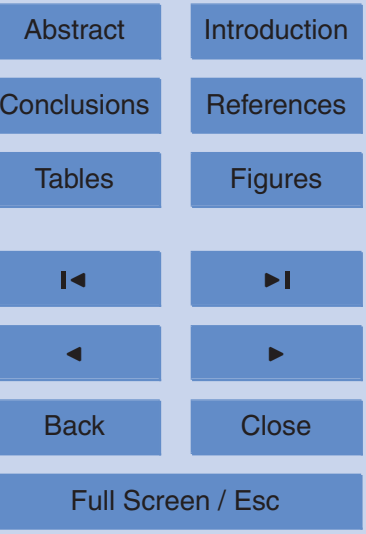

Printer-friendly Version

Interactive Discussion 
a)

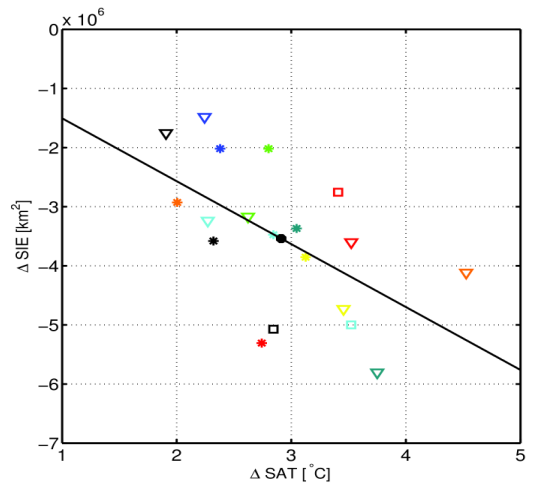

c)

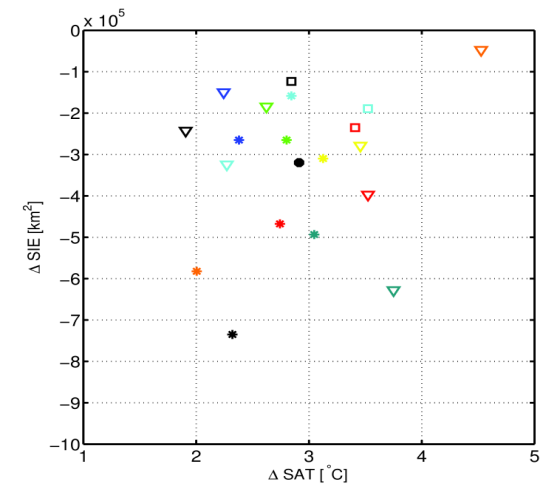

b)

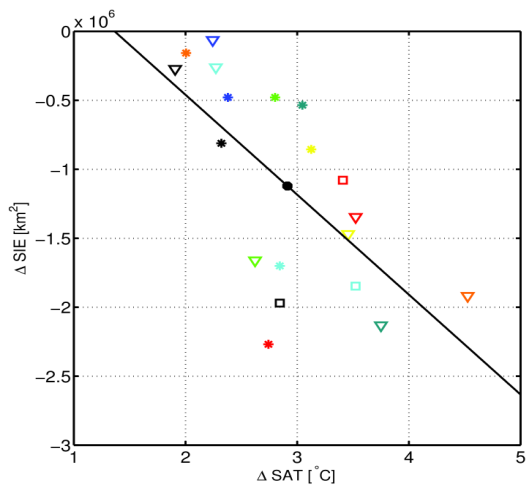

$$
\begin{array}{ll}
* \text { BCCR-BCM2.0 } \\
* \text { CCCMA-CGCM3.0(T47) } \\
* \text { CCCMA-CGCM3.1(T63) } \\
* \text { CNRM-CM3 } \\
* \text { CSIRO-MK3.0 } \\
* \text { CSIRO-MK3.5 } \\
\text { GFDL-CM2.0 } \\
* \text { GFDL-CM2.1 } \\
\nabla & \text { GISS-AOM } \\
\nabla & \text { GISS-MODEL-E-R } \\
\nabla & \text { INM-CM3.0 } \\
\nabla & \text { IPSL-CM4 } \\
\nabla & \text { MIROC3.2(hires) } \\
\nabla & \text { MIROC3.2(medres) } \\
\nabla & \text { MPI-ECHAM5 } \\
\nabla & \text { MRI-CGCM2.3.2a } \\
\square & \text { NCAR-CCSM3.0 } \\
\square \text { UKMO-HadCM3 } \\
\square \text { UKMO-HadGEM1 } \\
\text { - Multi-model mean } \\
\hline
\end{array}
$$

Fig. 5. Model sensitivity of the sea ice area of the Arctic against changes in surface air temperature of the Northern Hemisphere between the periods 1970-2000 and 2070-2100 for July, August and September; (a) the entire Arctic (correlation: -0.57), (b) the Central Arctic (correlation: -0.66) and (c) the Barents Sea.
The Arctic Sea ice in the CMIP3 climate model ensemble

L. K. Behrens et al.

Title Page

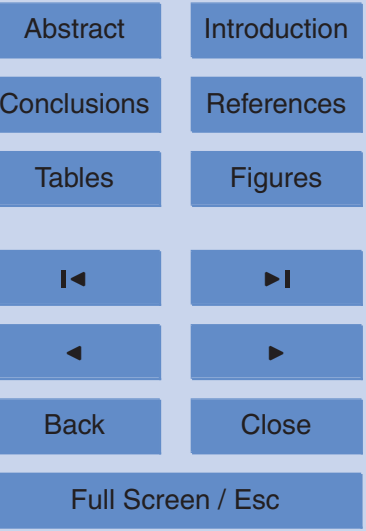

Printer-friendly Version

Interactive Discussion 
a)

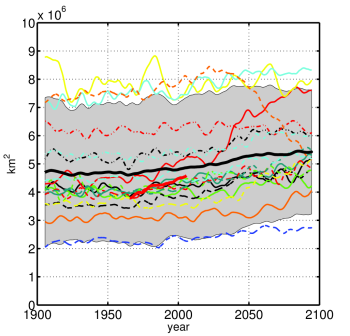

c)

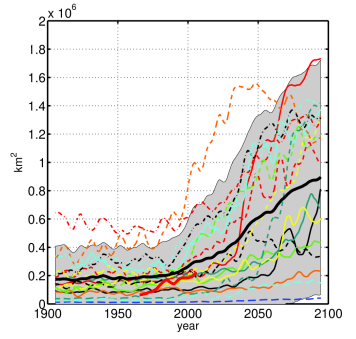

e)

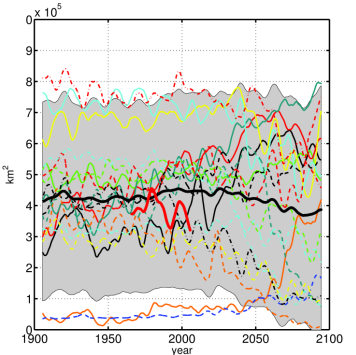

b)

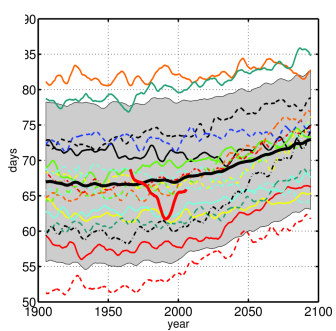

d)

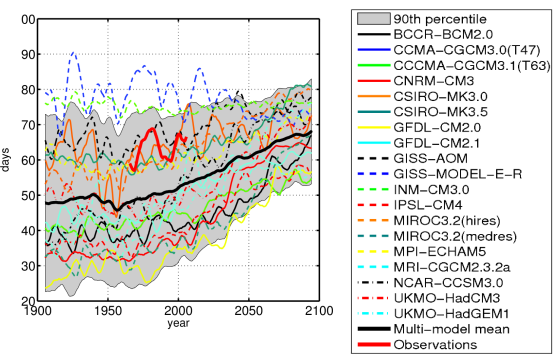

f)

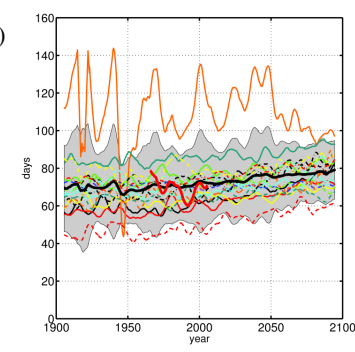

The Arctic Sea ice in the CMIP3 climate model ensemble

L. K. Behrens et al.

Title Page

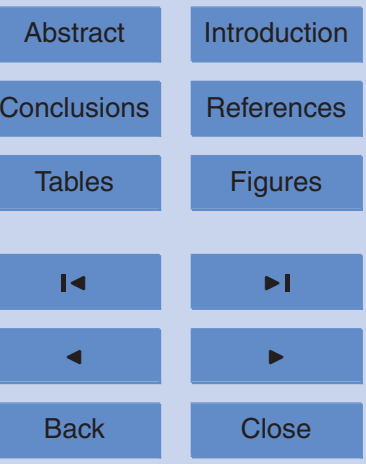

Full Screen / Esc

Printer-friendly Version Arctic (a, b), the Central Arctic (c, d) and the Barents Sea $(\mathbf{e}, \mathbf{f})$. The individual models are presented in different colors. The thick black line presents the model mean and the thick red line presents the observations. A five year mean has been applied. 
a)

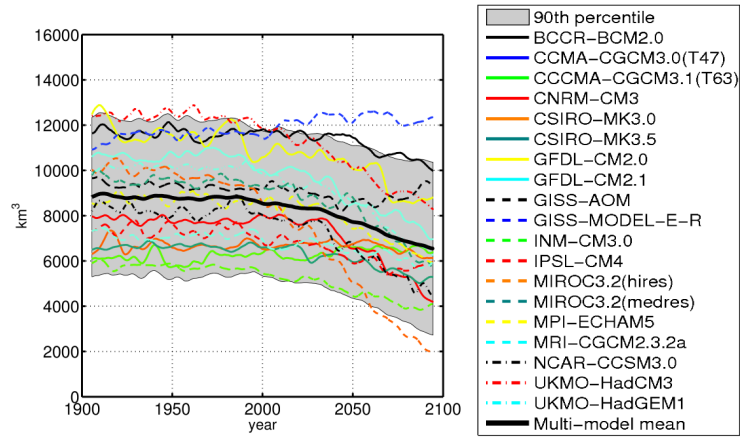

b)

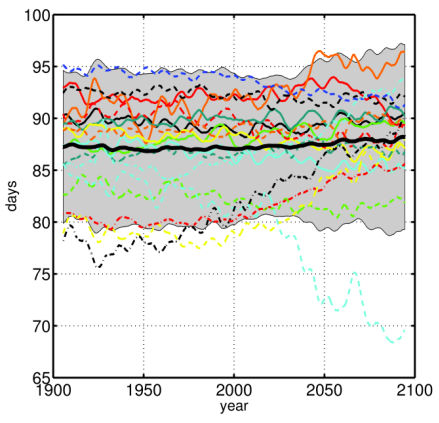

Fig. 7. Seasonal cycle of the Arctic sea ice volume: Amplitude (a) and phase (b) for individual models, a five year running mean has been applied.

The Arctic Sea ice in the CMIP3 climate model ensemble

L. K. Behrens et al.

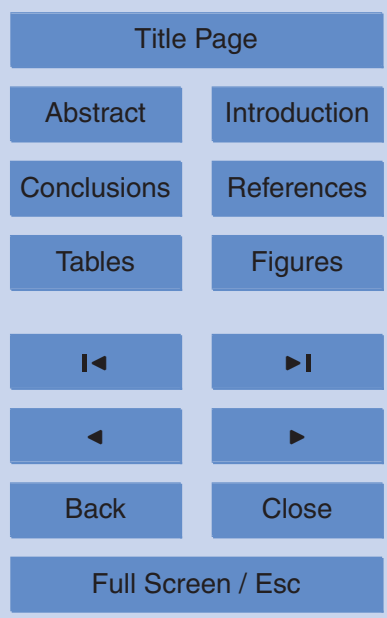

Printer-friendly Version

Interactive Discussion 
The Arctic Sea ice in the CMIP3 climate model ensemble
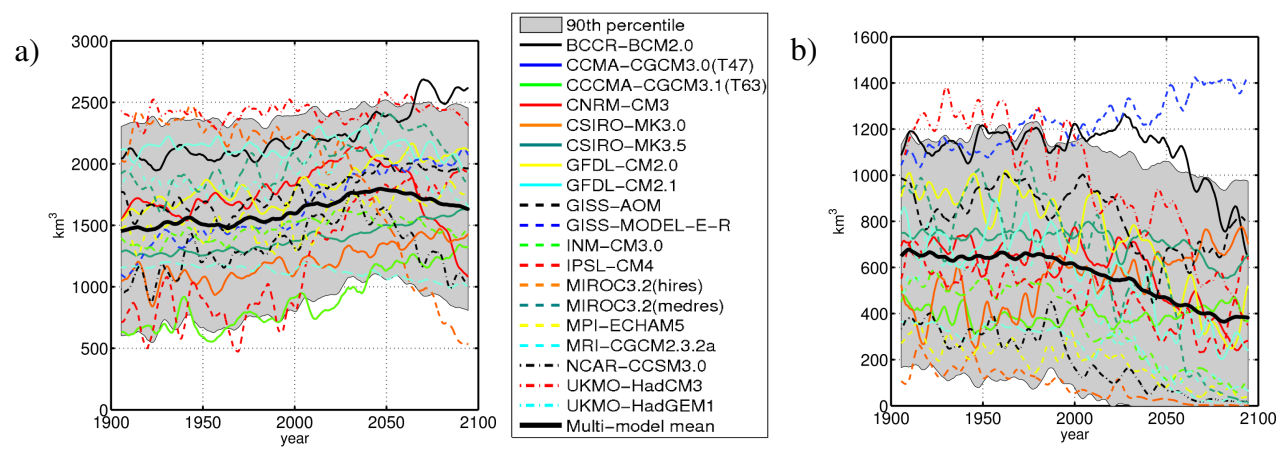

Fig. 8. Amplitude of the seasonal cycle of sea ice volume of the Central Arctic (a) and the Barents Sea (b). A five year running mean has been applied.
L. K. Behrens et al.

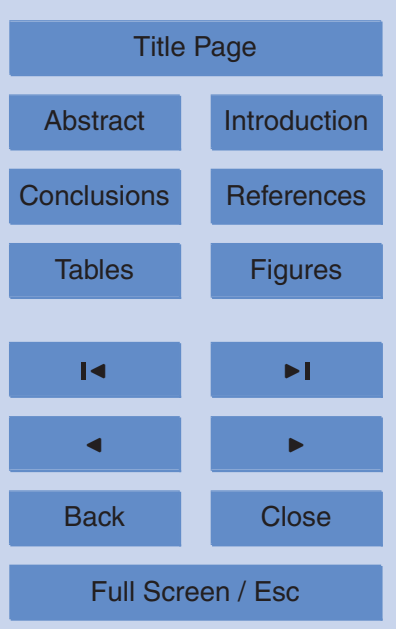

Printer-friendly Version

Interactive Discussion 


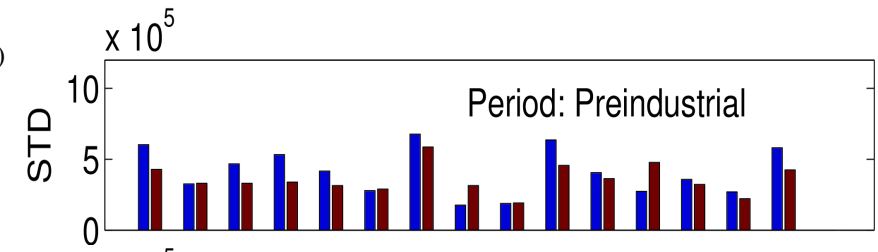

$$
\times 10^{5}
$$

b)

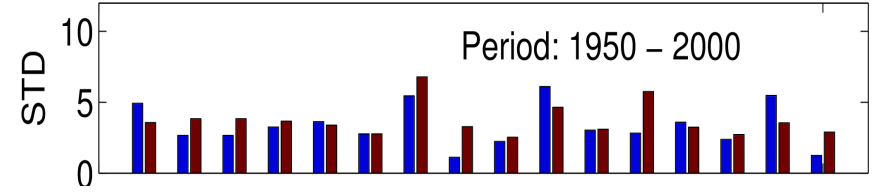

c) $\stackrel{5}{5}_{0}^{5}$

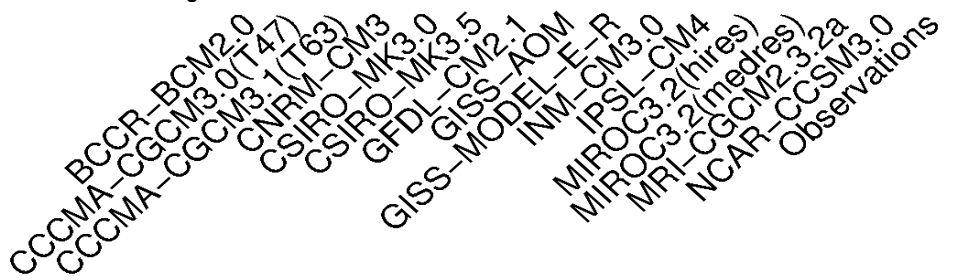

Fig. 9. Changes in standard deviation of sea ice area for the entire Arctic for March (blue) and September (red): preindustrial period (a), detrended time series of 20C3M period 1950-2000 and observation data (b), detrended time series of SRES A1B period 2050-2100 (c).
The Arctic Sea ice in the CMIP3 climate model ensemble

L. K. Behrens et al.

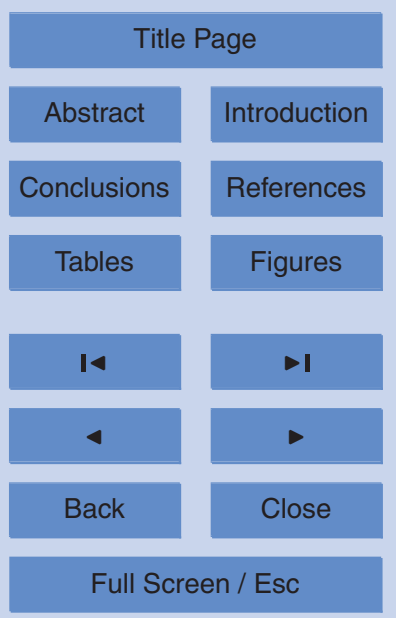

Printer-friendly Version

Interactive Discussion 
a)

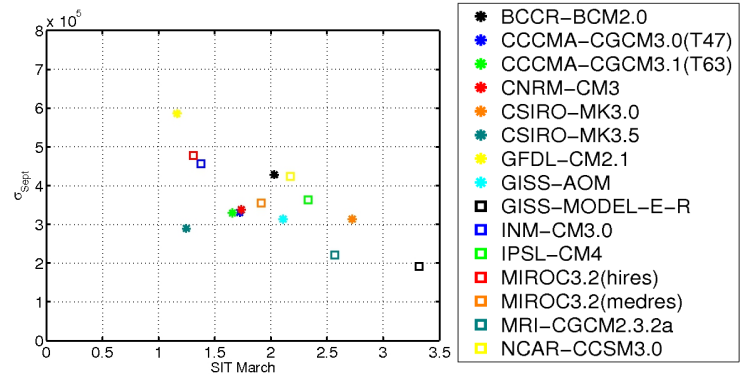

b)

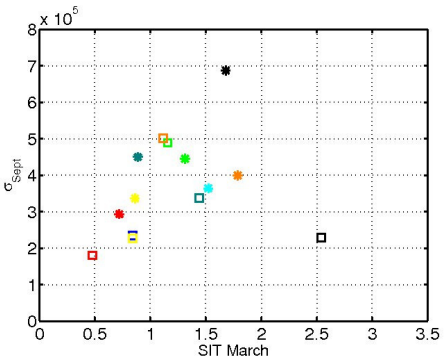

Fig. 10. Interannual standard deviation of sea ice area (September) against the sea ice thickness (March) for individual models; (a) preindustrial period (correlation coefficient: -0.68 ), (b) period 2050-2100 (0.23).

\section{TCD}

$6,5317-5344,2012$

The Arctic Sea ice in the CMIP3 climate model ensemble

L. K. Behrens et al.

Title Page

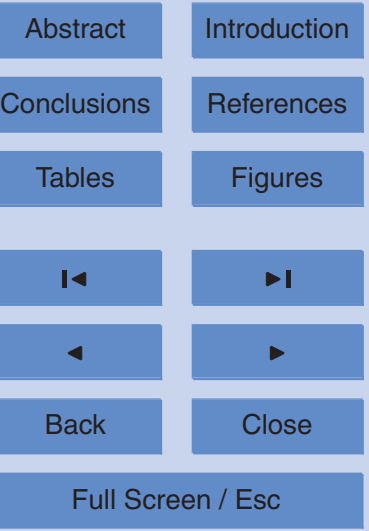

Printer-friendly Version

Interactive Discussion 